\title{
Sustainable Local Economic Development: The Role of Informatics in Determining Municipal Revenue Management
}

\author{
Michael Twum-Darko \\ Cape Peninsular University of Technology, South Africa \\ darkom@cput.ac.za
}

\begin{abstract}
This paper discusses the challenges undermining the ability of smaller municipalities in South Africa (SA) to raise revenue to sustain local economic development (SLED). The concept of enactment of technology-in-practice (ETiP) of Structuration Theory (ST) was adopted as a lens to understand and interpret the factors hindering the implementation of relevant legislation e.g., the municipal property rates Act of 2004 (MPRA) for SLED. The purpose of the study was to determine the role informatics can play in the implementation of MPRA to institutionalise its provisions to improve revenue collection. An extensive investigation in twenty-five (25) smaller municipalities across SA indicated a number of factors suggested by ETiP have impacted on the implementation of MPRA and property rates collection. The view is that implementation of legislation e.g., MPRA is similar to the deployment of ICT solutions in governments. Thus, in the world of social theory, legislation implementation is a socio-technical phenomenon with significant political, economic and social components. The findings of the study is a general framework as a lens through which factors influencing SLED can be understood and interpreted to provide a richer understanding of the complexity associated with the role of informatics in government revenue management to support SLED.
\end{abstract}

Keywords: Municipality; Information System; Legislation; Sustainability; Structuration Theory

\section{Introduction}

This paper discusses the challenges confronting smaller municipalities in South Africa (SA) to raise revenue to sustain local economic development (SLED). The research used the concept of enactment of technology-in-practice (ETiP) of Structuration Theory (ST) as a lens (see section 2 below) to understand and interpret the factors preventing sufficient implementation of legislation e.g., the municipal property rates Act of 2004 (MPRA) of South Africa in support of sustainable development. The paper further discusses the role informatics can play to implement MPRA to entrench its provisions to improve revenue collection and the management thereof. The discussions are based on data collected from 25 smaller municipalities across South Africa (see Appendix A) that are considered to be a good representation of municipalities (without the metros) as defined in section 40 of the South African Constitution, Act 108 of 1996. These municipalities are in areas considered to be underdeveloped: economically disadvantaged and socially underprivileged like many African towns and villages.

One way of making lives better and creating wealth in developing countries, particularly in Africa, is to ensure that any new legislation contributes to wealth creation and local economic development that is sustainable from an economic, social, and environmental point of view. This, to a large extent, is endorsed by Global Reporting Initiative (GRI) sustainable development strategy: Multistakeholder Engagement and Sustainability Reporting in Developing Countries (Global Reporting Initiative, 2012). The social and economic expectation of recipient of municipal services in many developing countries, especially in South Africa, is basic services such as good drinking water, affordable accommodation, accessible roads, basic education and good health infrastructure. Skill (2012, p. 1-16) argues that this has largely come to be true for activities that influence the running of environment and in this paper, particularly, the management of revenue and/or funds to deliver on the mandate of municipalities (South Africa Municipal Finance Management Act, 2003). Skill (ibid.) further reiterates that this social and economic expectation does not necessarily imply that individuals change their rates and local tax obligations. The obligations, from the perspective of this paper, have presented continuous and strained encounter between individual citizens, authorities and the political goal of sustainable development. In the case of South Africa, this has resulted in a number of service delivery protests. However, since the advent of the new political dispensation in 1994, there has been emphasis on reform initiatives which were meant to democratise the state and to 
empower and develop local communities (Benjamin in Heeks (ed.), 2000). This political changes since 1994 have had significant impact on the social structures of South African society.

Twum-Darko (2011) argues that the changes have been driven mainly by legislation with the purpose to institutionalise change across the country and to sustain local economic development. Legislation by its nature usually creates interactions and associations, and in the case of South Africa and its new liberal constitution, between the National Government, the Provincial Government and the Municipal and Local Councils (Twum-Darko, 2011). Twum-Darko (ibid.) further argues that some of these interactions are so complex that they create new political and social processes at the strategy planning level and have technological and social implications. Such implications as argued by Twum-Darko (2011, p. 12) create different scenarios one of which is the implementation of legislation which may require an informatics not thought of during the legislation design and promulgation to ensure its provisions and procedures are interpreted consistently and uniformly applied across time and space. The given scenario is what this study sought to address and which this paper discusses. Drawing from Koutifaris \& Mangioni (2012) view on sources of revenue from municipal rates and developer charges levied under Section 94 of North South Wales of local government areas, the study therefore examined the relationship between the provisions of a legislation using the Municipal Property Rates Act (MPRA) as an example and the approach needed to implement it and where informatics is considered as a major player in its implementation. The MPRA is designed to achieve two main objectives: to valuate all types of properties and accurately and equitably rate them.

Review of current work identified the main stream of academic and professional thinking relating to the role of socio-technical approaches to SLED. Within the work of Rip and Kemp (1998), Rotmans et al. (2001), Smith et al. (2005) and others over the years, areas such as legislation which are meant for social and economic reform were found not to have been emphasized enough as one of the drivers for social and economic development such as SLED. In the context of the paper and South Africa, the Municipal Systems Act, 2000 (Act 32 of 2000, p. 2) is one such example which provides for the core principles, mechanisms and processes that are necessary to enable municipalities to move progressively towards the social and economic upliftment of communities, and to ensure universal access to essential services that are affordable to all. The study, however, brought together the socio-technical approaches such as those found in their work and considered and applied them to understand and interpret the role of informatics and their influences on human actions and organisational reforms (Monteiro in Ciborra et al., 2001; Holmstrom \& Robey, 2002). It was also identified in the work of Dernbach (2008), Jenkins (2002), Porritt $(2009)$ and Ross $(2008,2010)$ that large-scale legislation for sustainable development where the exact approaches in the form of guidelines and policies to implement such legislation did not provide for the role of informatics or information systems and as such there have been few successes. However, the work of Esslinger (2009), Andrade \& Urquhart, (2010) and Pozzebon \& Diniz (2012) further points to the fact that the use of informatics have become invasive in organisations and society and the interplay is viewed as a means to create and sustain effectiveness. It is therefore expected that there will be a variety of outcomes even from the same technology and information system (Robey \& Boudreau, 2000). This is because the outcomes from the use of most technology and information systems are dependent on the social contexts e.g., SLED in which they are enacted (Orlikowski, 2000, Esslinger, 2009, Pozzebon \& Diniz, 2012). Drawing from Heeks \& Dave (2008) and given the above, the study is to understand and interpret the role informatics can play on the back of the provisions of legislation to sustain local economic development. As such the study employed Structuration Theory (ST) and in particularly the concept of Enactment of Technologies-in-Practice (ETiP) as a lens through which to understand and interpret the provisions of MPRA (a legislation) as human actions needed to support socially constructed phenomenon such as SLED and the structural conditions (i.e., the valuation process) which make their activities possible.

This paper presents an understanding and interpretation of a case study of challenges of implementing MPRA to support SLED. The research drew on the concept of ETiP as a lens through which to determine the role of informatics in implementing the MPRA as one of the major sources of revenue for local governments (municipalities). The paper has two objectives: (i) to present a theoretical understanding and interprets the concept associated with the point of view of using data from a real case study and (ii) to suggest a general framework that provides insight to the role of informatics in implementing MPRA to improve municipal revenue collection to sustain economic development initiatives and strategies. Given the above, this paper is structured as: 
- A brief overview of Structuration Theory and the concept of enactment of technology-in-practice (ETiP) used in the analysis of the case study;

- A summary of the methodology and the case narrative;

- Reinterpretation of the case study from the perspective of (ETiP); and

- The output as a general framework

\section{Theoretical Framework}

Overview of Enactment of Technology-in-Practice (ETiP): The overview first traces the various attempts that have been made in literature to "reconcile" ETiP: a concept in Structuration Theory (ST) with a real challenge of gaining a deeper understanding of municipal revenue management and SLED as functions of legislation e.g., MPRA and the role informatics can play in government revenue management to SLED. Twum-Darko (2011, p. 48-49) commented that ETiP allows legislation (e.g., MPRA) driving SLED to be seen as a duality of structure. In order to deepen the understanding of ETiP and how it is applied in the field of informatics which is relevant to this research, it is important to understand Giddens' (1986, p. 9-14) characterization of sociological enquiry, specifically of agency and structure as described in this section.

Agency/Agent and Structure are two of the central constructs of ST. Giddens (1986, p. 14), Giddens \& Pierson (1998) and Twum-Darko (2011) argue that human agency is the 'capacity to make a difference' (also known as 'transformative capacity') i.e., the flow or pattern of people's action and not people's intentions of doing things. Giddens (1986, p. 17 \& 377) further describes structure as resources and guidelines frequently implicated in the ETiP. According to Giddens (ibid.) guidelines are techniques used in the enactment of social practices. Therefore, as an example, on-going use of informatics strengthens technologies-in-practice and therefore becoming repeatedly used to carry out social life's demands such as revenue management and SLED. Hence deducing from Giddens (ibid.), 'rules and resources' are recursively implicated in the reproduction of social systems. Thus, structure is what gives form and shape to social life, but it is not itself the form and shape (Giddens, ibid). Structure, and in the context of this paper, ETiP exists only in and through the activities of human agents (Giddens 1989, p. 256). Walsham (1993, p. 34, 1995) describes action (or interaction) as having strongly reutilized aspects which is both conditioned by existing cultural structures and also creates and recreates those structures through the enactment process. By theorizing this social system, Giddens (ibid.) urged for a conceptualization of the contextuality of duality of structure and hence argued that "the constitution of agents and structure are not two independently given sets of phenomena: a dualism, but rather represent a duality." Thus, duality in ST refers to the way in which action and structure presupposes each other. Giddens (ibid.) further argues that "the structural properties of social systems are both medium and outcome of the practices they recursively organise." The latter which relates to, such as legislation impact on revenue management and SLED, is what this paper intends to elaborate.

Drawing from the work of Walsham $(1993,1995)$ and Orlikowski (2000), Twum-Darko (2011, p. 48-49) further argues that ETiP offers the window through which to analyse the structure and its formulation (action or interaction) as one that constitute a duality i.e., the structural characteristics affect the action, and in turn, the structure can be modified through action which results in a new structure which is the basis of the next change. Deducing from Orlikowski's structurational model of 'duality of technology' (Orlikowski, 1992 \& 2000), Twum-Darko (2011) furthermore argues that explicitly introducing material technology into the structure/agency duality, will enable social rules to be 'embedded' in "informatics" solutions during their design, but insisting that they cannot be programmatically read off by humans in a determinist manner (interpretive flexibility), a topic which is outside the scope of this paper. Orlikowski (2000, p. 407) used ETiP (see Figure 1) to further elaborate on the two notions of emergent structures and enactment, and indicated that structures are embodied in technologies to be appropriated by users (e.g., municipalities); while users may appropriate these differently from time to time and how, in the case of this paper, to identify other sources of revenue to sustain local economic development. "That is, rather than starting with the technology and examining how actors appropriate its embodied structures, this view starts with human action and examines e.g., legislation (i.e., MPRA), development (i.e., SLED agenda) and how it enacts emergent structures (e.g., Automation to collect and analyse of property data) through recurrent interaction with the technologies at hand" (op. cit.). Therefore, this structurational model (Figure 1) which is based on Giddens' model represents Orlikowski's argument of technology appropriation. 
Twum-Darko (2011, p. 92-101) in an attempt to further elaborate on Orlikowski's (2000, p. 410) concise description of the structurational model, repeats it verbatim: "When people use a technology, they draw on the properties comprising the technological artefact - those provided by its constituent materiality, those inscribed by the designers, and those added on by users through previous interactions (e.g., specific data attributes, customized features, or expanded software/hardware accessories). People also draw on their skills, power, knowledge, assumptions, and expectations about the technologies and its use, influenced typically by training, communication, and previous experiences. Users also draw on their knowledge and experiences with the institutional contexts in which they live and work, and the social and cultural conventions associated with participating in such contexts." The following understanding and interpretation were applied:

(a) Facility: Facility as one of the modalities that shape human interactions with structure, is a resource which is allocated such that it manifest itself to exert or exercise power (through ongoing, situated use of IS/Technology), and in turn, according to Giddens (1986 p. 25), produces and reproduces facilities influencing social structures of domination (i.e., Technologies-in-practice).

(b)Norm: Norms on the other hand as one of the modalities, refers to moral codes (e.g., millennium development goals), leadership (e.g., e-champions) and e-skills/skills understandings and endorsement for human interactions, which ultimately produces legitimation within structures (e.g., legitimizing through continuous usage - the provisions of legislation as functionality of IS/Technology).

(c)Interpretive Schemes: Structure (i.e., ETiP) and interaction (i.e., ongoing, situated use of IT/Technology) are associated with each other recursively via the linking modalities such as interpretive schemes (similar to Facility and Norm). As humans communicate, they use interpretive schemes (e.g., provisions of MPRA, etc) to help them make sense of their interaction and at the same time these interactions change or reproduce the same interpretive schemes (i.e., amendments to make them relevant) that are embedded in structures as signification (i.e., ETiP in turn providing a new view of the world).

Figure 1: Adaption of Enactment of Technology-in-Practice [Source: Orlikowski (2000)]

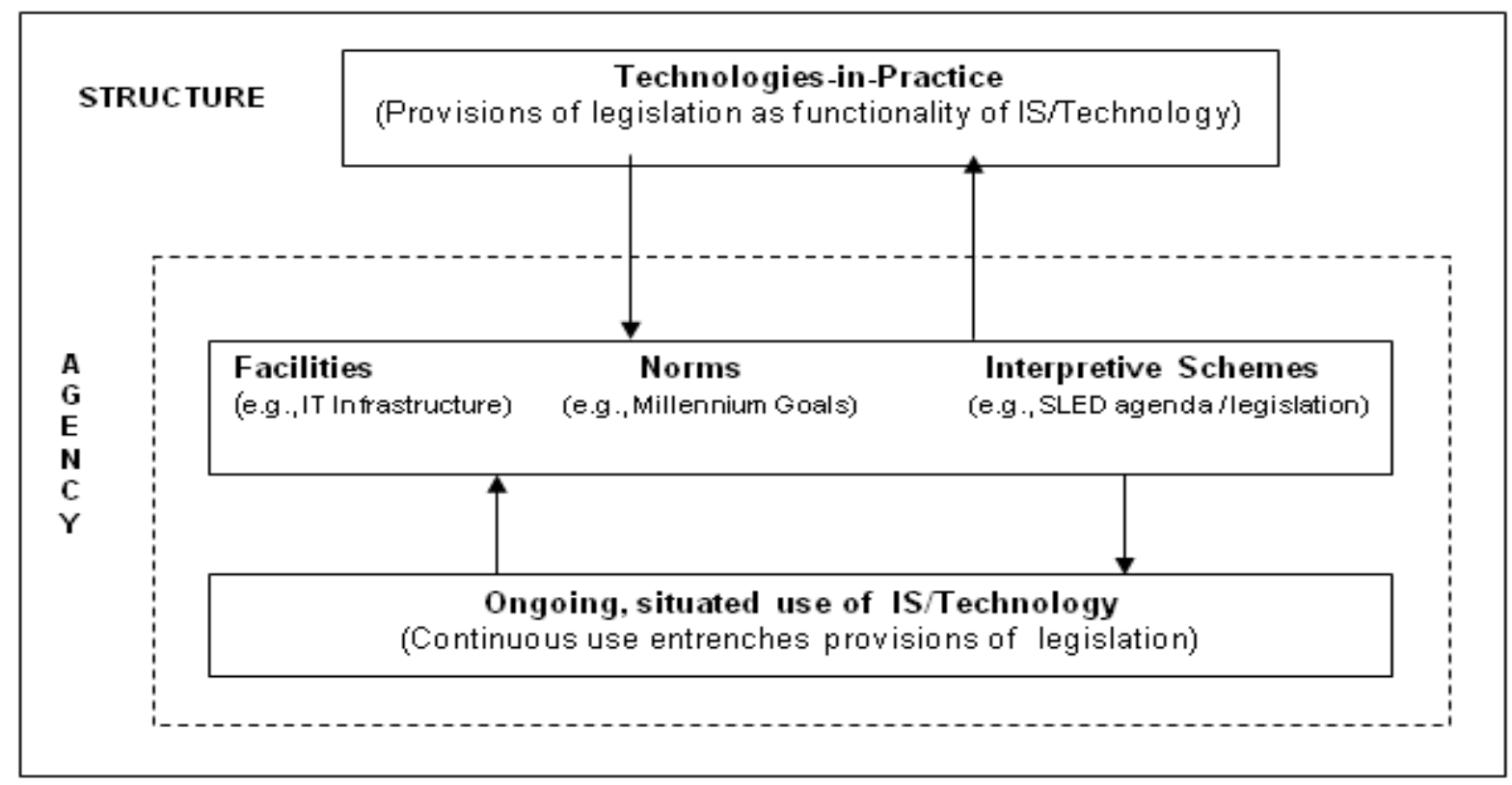

\section{The Case Study}

Background and Revenue Management Challenges: The South Africa Constitution (Act 108 of 1996) provides for a three-tier government system: National Government, Provincial Governments and Local Governments (Municipalities). The provincial governments are the nine (9) main regional governments of South Africa and each region has a number of municipalities; about 223 in total across South Africa. The constitution mandates municipalities to deliver services to the citizens in their jurisdiction, with powers to raise revenue or "to secure adequate and sustainable management for the financial affairs of municipalities and other institutions in the local sphere of government" (Municipal Finance Management 
Act, 2003 (Act 56 of 2003)) and to receive transfers from provincial and national governments i.e., service delivery accountability. It is this mandate which this paper attempts to understand and interpret how the role of informatics will facilitate the identification of sources of revenue to initiate and sustain local economic development. The Provincial Governments have the oversight role over Local Governments (Municipalities) and have exclusive powers of the National Government and concurrent powers as the National Government. The National Government has the mandate to formulate policies and regulations, an oversight role of both Provincial and Local Government and has major taxing powers. These mandates are distinctive in that each sphere has its own unique area of operation. The mandates are also interdependent which means that the three spheres are required to co-operate and acknowledge respective areas of jurisdiction and at the same time the constitutional mandates are interrelated ensuring that there is a system of cooperative governance and intergovernmental relations among the three spheres (section 40 of the South African Constitution, Act 108 of 1996).

Given the above, a reasonable proportion of the revenue management challenges of municipalities in South Africa emanate from the diverse nature of properties and settlements under a municipality's jurisdiction. Therefore, according to the Department of Provincial and Local Government (DPLG) (2007), an understanding of property and settlement types is critical for policy-makers seeking to create appropriate municipal institutions. DPLG (1998) further argues that municipalities therefore are faced with additional challenges, including the following:

- Properties and settlement dynamics have a major influence on the resource demands made on municipalities, particularly demands for access to basic services and infrastructure. Factors such as the population density and economic base of settlement influence proximity to bulk services, the cost of installing services and levels of affordability for households. Property types and settlement conditions therefore need to be taken into account when defining approaches to service delivery and appropriate municipal institutional arrangements.

- Changes in population distribution affect the size of suburbs and townships. Service delivery strategy needs to take into account, and anticipate, the population distribution and concentration which is to be served by any municipality.

- Extreme concentrations of taxable economic resources in formerly white areas, demanding redistribution between and within local areas.

- Huge backlogs in service infrastructure in historically underdeveloped areas, requiring municipal expenditure far in excess of the revenue currently available within the local government system.

- Great spatial separations and disparities between towns and townships and urban have spread out and as such municipalities in both rural and urban areas will need to develop strategies for spatial integration, while managing the continuing consequences of rapid urbanisation and service backlogs.

- Entrenched modes of decision-making, administration and delivery inherited from municipalities geared for the implementation of urban and rural apartheid.

- Inability to leverage private sector resources for development due to a breakdown in the relationship between capital markets and municipalities, the lack of a municipal bond market and the poor creditworthiness of some municipalities.

The constitutional mandate of MPRA now enables municipalities to create and sustain humane, equitable and viable human settlements and property types and to generate revenue to sustain them. It is doubtful whether most municipalities - as presently designed - are adequately equipped to fulfil this developmental mandate. Local government has been democratised, but the municipal systems are still structured to meet the demands of the previous dispensation. A fundamental transformation is therefore required.

\section{Methodology}

The methodology is a case study approach located in an interpretive paradigm. The underlying objective of this approach is to understand and interpret the social phenomenon, i.e., the role of informatics in government revenue management to sustain local economic development. This is to optimize the understanding of this complex social reality from the perspective of the capabilities of informatics which has the potential to influence the implementation of business and/or community/local economic development strategies. Drawing from Twum-Darko (2011, p. 107-134), ETiP was adapted to develop a theoretical understanding which provided a comprehensive interpretation of the results in terms of the role of informatics to institutionalise the provisions of MPRA to collect more property taxes to sustain 
local economic development. It must be noted that data was collected for the overarching research project in business and community informatics of which this paper forms a part.

Data was extracted from Strategic Plan Documents, Annual Reports, Audit Reports, Technology Infrastructure Policies, Corporate Governance Policy, Enterprise Architecture Strategy, Legal Frameworks, Project Management principles and a conducted unstructured interviews with staff (Senior, Middle and Operational management) of twenty-five (25) smaller municipalities which are tasked with the implementation of MPRA and local economic development initiatives. Most of the interviews lasted between one and half to two hours and they were all fully taped and transcribed. The investigation did not include the seven (7) Metro Cities of South Africa (e.g. City of Cape Town, etc) as previous work indicated that they have improved their capabilities to effectively raise and manage revenue for sustainable development and services delivery. In appendix A, the variables $M x$ (where $x$ is 1,2 , and $3 \ldots$ n) in Tables 2 and 3 represents different smaller municipality (not metro councils). The data collected covered the following types:

Table 1: Key characteristics of data collected

\begin{tabular}{llll}
\hline & Revenue Type & & Informatics Type \\
\hline 1 & Property rates & 1 & Technology/Technical infrastructure \\
2 & Service charges & 2 & Legal infrastructure \\
3 & Rental of facilities and equipment & 3 & Institutional infrastructure \\
4 & Interest earned/ Dividends/Public Contributions & 4 & Enterprise Architecture \\
& \& Donations & & \\
5 & Fines (traffic fines)/ Licences and permits & 5 & Human infrastructure \\
6 & 6 & E-Leadership \\
7 & Government grants and subsidies & & \\
\hline Note: & The informatics type (Source: Heeks (2008) "Success and Failure of eGovernment Projects")
\end{tabular}

The creation of Enactment of Technologies-in-Practice (ETiP): The role of informatics in government revenue management is driven from the role of information system in implementing MPRA to support SLED at municipalities and is considered as a process of ETiP. The promulgation of MPRA, according to Twum-Darko (2011, p. 136-153), is meant to improve revenue of municipalities and to address inequity in property valuation and taxation in South Africa. As a mandate from the two houses of South African parliament, municipalities, have to put in place the necessary infrastructure which includes adequate IT systems and infrastructure to effectively implement the MPRA. Therefore, the analysis started with the investigation of how MPRA has been implemented in the 25 municipalities. The rationale was on the assumption that one of the channels to source in and effectively manage revenue is through MPRA effective implementation and use; and that the role of informatics from the view point of Rolland \& Monteiro (2002) is a major ETiP. The latter was already being pursued or to be pursued by the management of municipalities interviewed. We then traced the ETiP in the context of the role of informatics in MPRA implementation and how the provisions of MPRA have been entrenched in information systems as functionality (Twum-Darko, 2011, p. 156-208) to improve property rates collection as additional revenue for municipalities in support of local economic development at the selected municipalities.

\section{Results and Discussion}

The Table 2 (see Appendix A) illustrates revenue type data collected from the 25 municipalities, each showing the average percentage contribution to the total revenue over 5 years. Given Table 2, a general framework was developed on the basis of ETiP. The implications are that there are factors that have prevented adequate implementation of MPRA as a means to raise and manage additional revenue for the 25 municipalities investigated. This represented fairly, the situation at the remaining 210 municipalities in South Africa. Thus, from Table 2, property rates collection contributes to an average of $17 \%$ of the total revenue of municipalities. This is far less than the global trend of $28-30 \%$ (Williams, 2010). This is a serious loss of revenue to the municipalities which should, in terms of the global trend, become one of the major contributors to the total annual revenue of the municipalities. Data collected indicated that the main sources of revenue for municipalities are service charges (i.e., water, electricity, sewerage and refuse) and national government transfers to them. The two sources amounted to $80 \%$ of the total annual 
revenue. In terms of the Municipal Systems Act, national government contribution to municipalities, annually, is $20 \%$ of total revenue. Given Table 2, it appears only two municipalities (M1 and M18) survived with the $20 \%$ during the 5 years as the data has suggested. The rest have to ask for additional funding (i.e., over and above the $20 \%$ ) from the National Government to sustain local activities including economic development. Using the general framework as a lens to determine what might have gone wrong, it became apparent that the following factors which are in 3 broad categories and illustrated in Table 3 (see Appendix A) prevented sufficient implementation of MPRA across the municipalities interviewed. They also demonstrate that most of the municipalities interviewed are NEAR READY $(3=$ medium impact) to take advantage of informatics to increase revenue. Thus, from Table 3 in Appendix A, 1 and/or 2 (i.e., low impact) indicate that the municipality is NOT READY to take advantage of informatics to implement MPRA as legislation to improve revenue collection. Scoring 4 and/or 5 (i.e., high impact), a municipality is READY. These are further explained from the perspective of ETiP as follows:

(a)Facilities: Unaligned business processes, the absence of effective mass appraisal system which has created huge paper-based filing systems and extensive manual processes and limited integration of IT systems prevented the municipalities to determine the property rates revenue, improve collection and management thereof. The aforementioned limitations also affected quality of property data collected and as such created pockets of inequality and inequity in the valuation rolls.

(b)Norm: It was identified that the following also prevented sufficient implementation of MPRA: the absence of eGovernment champions and inadequate ICT leadership; lack of coherent strategy for ICT for development; non-aligned governance structures impacting on ICT decisions; and lack of formalized reporting and management information system.

(c)Interpretive scheme: Inadequate knowledge of how to implement MPRA to derive maximum benefits from the provisions of the Act has affected their ability to use property rates as means to increase revenue for local development. Also politicisation of municipal services have led to nepotism and favouritism in service delivery due to bad judgment and poor property data collection thus leading to low collection of property rates/taxes. All the municipalities interviewed have no visible and predictable integrated SLED agenda.

\section{Conclusion and Recommendations}

Municipalities are like any organization whose main mandate is to deliver basic services to the public. As such are to be driven by informatics enabled organizational transformation initiatives like automated mass appraisal (AMA) of properties. Therefore, the readiness of these municipalities to implement AMA on the back of MPRA can be studied using the concept of ETiP. ETiP therefore can be used as a lens through which to understand and interpret the role of informatics in municipal (government) revenue management to sustain local economic development. The research output (Figure 2) which is the general framework: Informatics-eLeadership-Legislation (IDeL) and based on ETiP, further demonstrates the importance of informatics (see Table 3) in driving and improving revenue collection for SLED. The IDeL as a general framework also suggests that SLED can be studied using technological determinism and from the perspective of social construction of technology as argued by Twum-Darko (2011, p. 46-50) and Barley (1990). The outcome of the study recommends the following:

Figure 2: General Framework: Informatics-eLeadership-Legislation (IDeL)

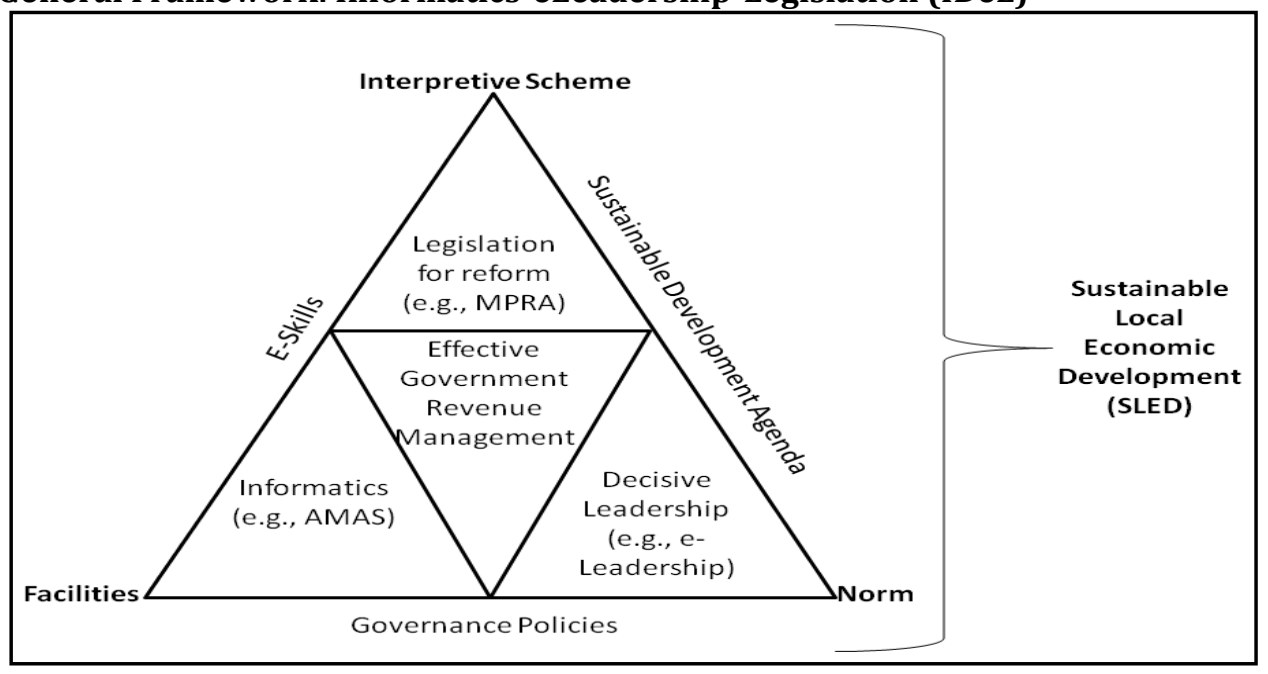


(a) Informatics: Given Table 3 in Appendix A, strategic and technology partnership with the private sector will improve the technical infrastructure of majority of municipalities to:

- Develop new business processes and implement AMA system to improve the collection and quality of property valuation data,

- Improve quality of property valuation to create equality and equity in property rating;

- Implement enterprise content management to improve document management, workflow and access to information; and

- Properly, strategically and effectively integrate IT systems to collect and manage property rates and revenue.

(b) e-Leadership: The need to introduce e-Government champions (or e-Champions) and the need to establish ICT leadership was identified (Table 3 - Appendix A). A need was identified to ensure coherent strategy for ICT for local economic development to reverse growing poverty. It was also identified that all governance structures impacting on ICT decisions need to be aligned. The final need was the formalization of organisational reporting on the achievement and success of sustainable development goals to measure the extent of the implementation of the provisions of the legislation. It is envisaged that AMA will eliminate bad judgment and poor property data collection thus leading to increased collection of property rates/taxes. AMA will therefore drive the municipalities to have visible and predictable integrated SLED agenda. There was also the need to improve the e-Leadership capabilities of municipalities to drive not only AMA but also IT infrastructure integration.

(c)Legislation for reform: Table 3 (see Appendix A) illustrates the need to increase, among municipal staff (not only the finance department), the MPRA knowledge and the benefits of implementing it through the use of informatics (i.e., to institutionalize the provisions of the Act as it is routinely used via an information system - AMAS). The "spirit" of MPRA and which this paper determined, is to derive adequate taxation or rating of properties in the jurisdiction of municipalities to bring in the needed revenue for development and to sustain development. Thus, effective MPRA implementation is the use of informatics to rollout AMA to support property rating. This was found to be the means with which municipalities can improve the property rates contribution of the total annual revenue from $17 \%$ to $30 \%$ in line with global trend. Though the study did look at the challenges of revenue collection e.g., indigent citizens, party politics, they are not considered in this paper. Given the above, effective government revenue management is possible with IDeL to sustain the development within each municipal boundary. Thus, IDeL will help create economic opportunities e.g., job creation, entrepreneurship, employers, and to improve service delivery to reduce socially underprivileged communities in developing countries like Africa.

\section{References}

Andrade, D. A. \& Urquhart, C. (2010). The affordances of actor network theory in ICT for development research. Information Technology \& People, 23(4), 352-374

Barley, S. (1990). The alignment of technology and structure through roles and networks. Administrative Science Quarterly, Special Issue: Technology, Organizations, and Innovation, 35(1), 61-103.

Benjamin, P. (2001). Community development and democratisation through information technology: building the new South Africa. In: R.B. Heeks (Ed), Reinventing Government in the Information Age, 194-210, Routledge, London.

Department of Provincial and Local Government (DPLG). (1998). White Paper on Local Government. Retrieved March 3, 2013, from: http://www.thedplg.gov.za/subwebsites/wpaper/wp1.htm.

Department of Provincial and Local Government (DPLG). (2007). Policy Process on the System of Provincial and Local Government. Retrieved March 3, 2013, from: www.pmg.org.za/docs/2007/070731dg.htm.

Dernbach, J. (2008). Navigating the U.S. transition to sustainability: Matching national governance challenges with appropriate legal tools. Tulsa Law Review, 44, 93-120.

Esslinger, H. (2009). How Design Strategies Are Shaping the Future of Business. San Francisco CA: John Wiley \& Sons.

Giddens, A. (1986). The constitution of society: Outline of the theory of structuration. Berkeley CA: University of California Press.

Giddens, A. (1989). Sociology, Polity Press, United Kingdom.

Giddens, A. \& Pierson, C. (1998). Conversations with Anthony Giddens. Cambridge: Polity Press. 
Global Reporting Initiative. (2012). Annual Report: 2011/12. Retrieved March 4, 2013, from: https://www.globalreporting.org/resourcelibrary/GRI-Annual-Report-2011-2012.pdf.

Heeks, R. (2008). Success and Failure in eGovernment Projects. Retrieved July 2, 2014, from: http://www.egov4dev.org/success/

Heeks, R. \& Dave, R. K. (2008). Avoiding eTransparency Failure: Ideas about Politics and Self-Interest. Retrieved September 12, 2013, from: https://www.egov4dev.org/transparency/techniques/factors_politics.shtml.

Holmstrom, J. \& Robey, D. (2002). Inscribing Organizational Change with Information Technology: An Actor Network Theory Approach. Retrieved July 2, 2014, from: URL: http://www.informatik.umu.se/gru/kurssidor/2004/ht/infd04/itbe/ume/pdfdokument/Holms trom-Robey.pdf.

Jenkins, V. (2002). Placing sustainable development at the heart of government in the UK: The role of Law in the evolution of sustainable development as the central organising principle of government. Legal Studies, (22), 578-602.

Koutifaris, K. \& Mangioni, V. (2012). Rates versus Developer contributions as revenue sources for local government. Commonwealth Journal of Local Governance, (11), 53-75. Retrieved August 17, 2013, from: http://epress.lib.uts.edu.au/ojs/index.php/cjlg

Monteiro, E. (2001). Actor-Network Theory and Information Infrastructure. In: C.U. Ciborra et al., (ed.), From Control to Drift: The Dynamics of Corporate Information Infrastructures. Oxford: Oxford University Press.

Orlikowski, W. J. (1992). The Duality of Technology: Rethinking the Concept of Technology in Organizations. Organization Science, 3(3), 398-427.

Orlikowski, W. J. (2000). Using technology and constituting structures: A practice lens for studying technology in organizations. Organization Science, 11(4), 404-428.

Porritt, J. (2009). The standing of sustainable development in government, 10; Retrieved September 12, 2013, from: http://www.jonathonporritt.com/blog/standing-sustainable-developmentgovernment.

Pozzebon, M. \& Diniz, E. H. (2012). Theorizing ICT and society in the Brazilian context: a multilevel, pluralistic and remixable framework. BAR, Braz. Adm. Review, (9)3, 287-307.

Rip, A. \& Kemp, R. (1998). Technological change. In: Human choice and climate change. Resources and technology, 2, 327-399. Battelle Press, Columbus, $\mathrm{OH}$.

Robey, D. \& Boudreau, M. C. (2000). Organizational consequences of information technology: Dealing with diversity in empirical research. In: R. W. Zmud, (Ed.), Framing the domains of IT management: Projecting the future through the past. Cincinnati, Pinnaflex Education Resources.

Rolland, K. H. \& Monteiro, E. (2002). Balancing the local and the global in infrastructural information systems. The Information society, 18(2), 87-100.

Rotmans, J., Kemp, R. \& Asselt, M. (2001). More Evolution than Revolution: Transition Management in Public Policy. Foresight. The Journal of Futures Studies, Strategic Thinking and Policy, 3(1), 15-31. Retrieved July 2, 2014, from

Ross, A. (2010). It's Time to Get Serious - Why legislation is needed to make sustainable development a reality in the UK. Sustainability. 2, 1101-1127. Retrieved August 16, 2013, from: http://www.oalib.com/paper/170223\#.Uq96beJvVsw.

Ross, A. (2008). Why legislate for sustainable development? An examination of sustainable development provisions. In UK and Scottish statutes. J. Environ. Law, 20, 35-68.

RSA. (2000). Municipal Systems Act, 32 of 2000. Retrieved March 15, 2013, From: www.lawsofsouthafrica.up.ac.za.

Skill, K. (2012). The What, Who, and How of ecological action space. Sustainability, 4(1), 1-16.

Smith, A., Stirling, A. \& Berkhout, F. (2005). The governance of sustainable sociotechnical transitions. Research Policy, 34, 1491-1510.

Twum-Darko, M. (2011). The Role of Information Systems in Legislation Led Reform: A case study in the context of the new municipal property rates Act of South Africa. Germany: LAP Lambert Academic Publishing, 46-50, 202-203.

Walsham, G. (1993). Interpretive information systems in organizations. Chichester: John Wiley \& Sons.

Walsham, G. (1995). Interpretive case studies in IS research: nature and method. European Journal of Information Systems, 4, 74-81.

Williams R. (2010). State and local tax policy: What are the sources of revenue for local governments? In: The tax policy briefing book: A citizens' guide for the 2008 election and beyond, 2. Retrieved April 12, 2013, from: http://www.taxpolicycenter.org/upload/Statelocal/IV1STATEOFLOCALTAXPOLICY.final.pdf. 
Appendix A

Table 2: Percentage contribution to total revenue by revenue type

TWENTY-FIVE (25) MUNICIPALITIES INVESTIGATED

\begin{tabular}{|c|c|c|c|c|c|c|c|c|c|c|c|c|c|c|c|c|c|c|c|c|c|c|c|c|c|c|}
\hline $\begin{array}{l}\text { Revenue } \\
\text { Type }\end{array}$ & $\begin{array}{l}\text { M } \\
1 \\
\text { Per }\end{array}$ & $\begin{array}{l}\text { M } \\
2 \\
\text { ent }\end{array}$ & $\begin{array}{c}\text { M } \\
3 \\
\text { ge o } \\
\end{array}$ & $\begin{array}{l}\text { M } \\
4 \\
\text { Tot }\end{array}$ & $\begin{array}{l}\text { M } \\
5 \\
\text { AnI } \\
\end{array}$ & $\begin{array}{c}M \\
6 \\
\text { ual F }\end{array}$ & $\begin{array}{c}M \\
7 \\
\text { evel }\end{array}$ & $\begin{array}{c}\text { M } \\
8 \\
\text { ue }\end{array}$ & $\begin{array}{l}M \\
9\end{array}$ & $\begin{array}{l}\text { M1 } \\
\mathbf{0}\end{array}$ & $\begin{array}{l}\text { M1 } \\
1\end{array}$ & $\begin{array}{l}\text { M1 } \\
2\end{array}$ & $\begin{array}{l}\text { M1 } \\
3\end{array}$ & $\begin{array}{l}\text { M1 } \\
4\end{array}$ & $\begin{array}{l}\text { M1 } \\
5\end{array}$ & $\begin{array}{l}\text { M1 } \\
6\end{array}$ & $\begin{array}{l}\text { M1 } \\
7\end{array}$ & $\begin{array}{l}\text { M1 } \\
8\end{array}$ & $\begin{array}{l}\text { M1 } \\
9\end{array}$ & $\begin{array}{l}\text { M2 } \\
\mathbf{0}\end{array}$ & $\begin{array}{l}\text { M2 } \\
1\end{array}$ & $\begin{array}{l}\text { M2 } \\
2\end{array}$ & $\begin{array}{l}\text { M2 } \\
3\end{array}$ & $\begin{array}{l}\text { M2 } \\
4\end{array}$ & $\begin{array}{l}\text { M2 } \\
5\end{array}$ & AVG \\
\hline $\begin{array}{l}\text { Property } \\
\text { rates } \\
\text { Service }\end{array}$ & 17 & 18 & 19 & 17 & 18 & 19 & 17 & 16 & 13 & 14 & 19 & 18 & 17 & 19 & 19 & 18 & 14 & 18 & 13 & 16 & 13 & 18 & 14 & 15 & 18 & $\begin{array}{l}17 \\
\% \\
46\end{array}$ \\
\hline $\begin{array}{l}\text { charges } \\
\text { Rental of } \\
\text { facilities } \\
\text { and }\end{array}$ & 54 & 47 & 51 & 50 & 31 & 56 & 51 & 51 & 38 & 43 & 28 & 30 & 51 & 46 & 51 & 50 & 50 & 53 & 55 & 47 & 53 & 30 & 51 & 51 & 30 & $\%$ \\
\hline $\begin{array}{l}\text { equipment } \\
\text { Interest }\end{array}$ & 1 & 1 & 2 & 1 & 2 & 1 & 1 & 1 & 1 & 2 & 1 & 2 & 1 & 1 & 1 & 1 & 1 & 1 & 1 & 2 & 1 & 2 & 1 & 1 & 2 & $1 \%$ \\
\hline $\begin{array}{l}\text { earned } \\
\text { Dividends/P } \\
\text { ublic } \\
\text { Contributio }\end{array}$ & 2 & 0 & 1 & 1 & 1 & 0 & 0 & 1 & 0 & 1 & 0 & 1 & 0 & 1 & 2 & 0 & 0 & 2 & 0 & 1 & 0 & 1 & 1 & 1 & 1 & $1 \%$ \\
\hline $\begin{array}{l}\text { ns } \\
\text { Fines } \\
\text { (traffic }\end{array}$ & 1 & 1 & 1 & 2 & 1 & 0 & 0 & 0 & 0 & 0 & 0 & 0 & 1 & 2 & 1 & 0 & 0 & 1 & 0 & 1 & 0 & 0 & 0 & 1 & 0 & $1 \%$ \\
\hline $\begin{array}{l}\text { fines) } \\
\text { Licences }\end{array}$ & 0 & 5 & 2 & 0 & 13 & 0 & 0 & 1 & 3 & 1 & 0 & 4 & 0 & 1 & 0 & 0 & 0 & 0 & 0 & 5 & 0 & 4 & 1 & 1 & 4 & $2 \%$ \\
\hline $\begin{array}{l}\text { and permits } \\
\text { Government } \\
\text { grants and }\end{array}$ & 0 & 1 & 2 & 2 & 8 & 0 & 1 & 1 & 0 & 1 & 1 & 2 & 1 & 4 & 0 & 0 & 0 & 0 & 0 & 1 & 0 & 2 & 1 & 1 & 2 & $\begin{array}{l}1 \% \\
28\end{array}$ \\
\hline $\begin{array}{l}\text { subsidies } \\
\text { Other }\end{array}$ & 19 & 23 & 21 & 22 & 24 & 24 & 30 & 28 & 44 & 35 & 41 & 35 & 28 & 22 & 23 & 27 & 31 & 19 & 30 & 23 & 27 & 35 & 27 & 25 & 35 & $\%$ \\
\hline income & $\begin{array}{l}6 \\
10\end{array}$ & $\begin{array}{l}4 \\
10\end{array}$ & $\begin{array}{l}1 \\
10\end{array}$ & $\begin{array}{l}5 \\
10\end{array}$ & $\begin{array}{l}2 \\
10\end{array}$ & $\begin{array}{l}0 \\
10\end{array}$ & $\begin{array}{l}0 \\
10\end{array}$ & $\begin{array}{l}1 \\
10\end{array}$ & $\begin{array}{l}1 \\
10\end{array}$ & $\begin{array}{l}3 \\
10\end{array}$ & $\begin{array}{l}10 \\
10\end{array}$ & $\begin{array}{l}8 \\
10\end{array}$ & $\begin{array}{l}1 \\
10\end{array}$ & $\begin{array}{l}4 \\
10\end{array}$ & $\begin{array}{l}3 \\
10\end{array}$ & $\begin{array}{l}4 \\
10\end{array}$ & $\begin{array}{l}4 \\
10\end{array}$ & $\begin{array}{l}6 \\
10\end{array}$ & $\begin{array}{l}1 \\
10\end{array}$ & $\begin{array}{l}4 \\
10\end{array}$ & $\begin{array}{l}6 \\
10\end{array}$ & $\begin{array}{l}8 \\
10\end{array}$ & $\begin{array}{l}4 \\
10\end{array}$ & $\begin{array}{l}4 \\
10\end{array}$ & $\begin{array}{l}8 \\
10\end{array}$ & $\begin{array}{l}4 \% \\
100\end{array}$ \\
\hline Total & 0 & 0 & 0 & 0 & 0 & 0 & 0 & 0 & 0 & 0 & 0 & 0 & 0 & 0 & 0 & 0 & 0 & 0 & 0 & 0 & 0 & 0 & 0 & 0 & 0 & $\%$ \\
\hline
\end{tabular}


Table 3: Readiness for Automated Mass Appraisal (AMA) in Property Rating

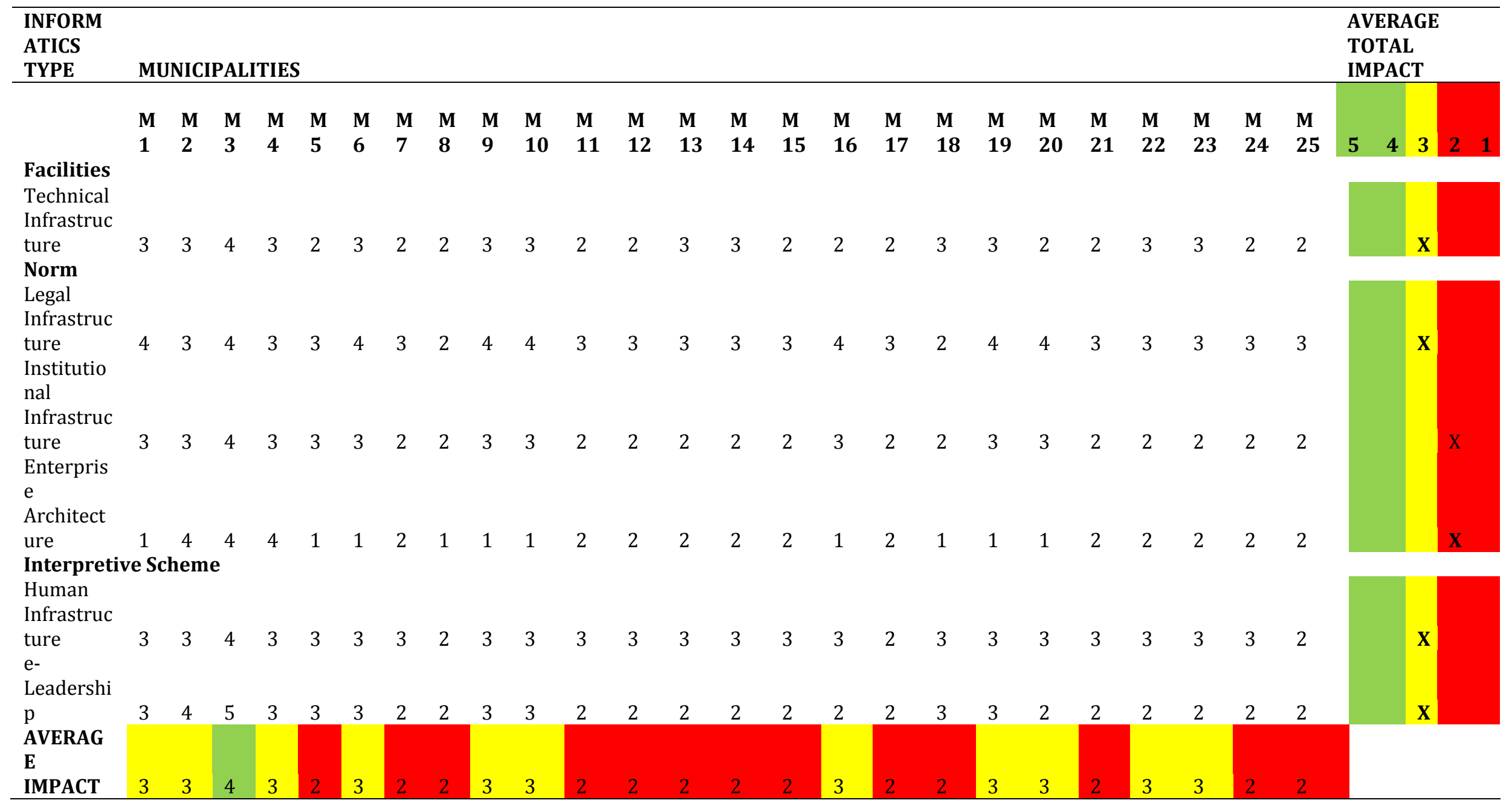

Legend: 5 and 4 = High Impact (Ready); 3 = Medium Impact (Near Ready); 2 and 1 = Low Impact (Not Ready) 